\title{
Development of new types of combined meat products and dynamic changes depending of their indicators on various technological stages of production
}

\author{
Gadimova Natavan SAFAR ${ }^{1}$, Akhundova Nazila ABDUL ${ }^{1 *}$ (D), Babashli Aynur AMIRKHAN ${ }^{1}$, \\ Shahla Yusifzada NATIQ ${ }^{2}$
}

\begin{abstract}
Currently, there is a deficiency of protein, vitamins, macro- and microelements in the diet of people. When processing and manufacturing meat, a large amount of co-products is obtained that have a high nutritional value, are a source of protein, minerals and vitamins, etc. Therefore, the rational use of co-products in the production of meat products is relevant in terms of solving the problem of the growing demand for protein. The article is devoted to the development of two new types of sausages. Based on the research results, a recipe for two new types of meat products has been developed using liver and carrots. In the finished meat products, organoleptic indicators, $\mathrm{pH}$, moisture, ash, fat, protein, vitamins, minerals, carbohydrates, sodium nitrite were determined. It was revealed that at the technological stages of the manufacture of meat products, biochemical processes occur that determine a decrease in the level of amino acids, the content of proteins, fats, vitamins, etc. The qualitative and quantitative composition of free and bound amino acids of proteins of meat products is determined, their usefulness in relation to essential and limiting amino acids, the content of proteins, fats, carbohydrates, etc. is indicated.
\end{abstract}

Keywords: meat protein; combined meat products; prescription; technological stages; production prototypes.

Practical Application: The formulation of new types of sausages using beef heart and carrots has been developed.

\section{Introduction}

At present, the problem of increasing the food and biological value of food products with the rational use of domestic raw materials remains urgent. Plant raw materials containing biologically active components play a special role (Kajibayeva et al., 2013; Tyugai, 2004; Karwowska et al., 2014; Pluschke et al., 2018; Kryževičǔte et al., 2017).

Products of animal origin are much richer in amino acids in comparison with plant foods. Proteins of animal origin are not only well absorbed, but also increase the assimilation of plant origin proteins, which enables to balance the amino acid composition of food. For satisfying the amino acid needs of the body, it is expedient to use a different combination of products (Aslanova et al., 2010; Rodionova et al., 2015).

In this relation, there arises a need in procuring the sources of animal protein, in particular, raw materials such as co-products. Meat co-products are the non-meat components arising from meat processing/fabrication and are generated in large quantities on a daily basis. Co-products are considered as low added-value products, and in general it is difficult for industries to divert efforts into increasing their value. While many of these products can be edible those not used for human consumption or pet food is usually processed to be used as animal feed, fertilizer or fuel. However, to a large extent meat co-products are an excellent source of high nutritive value protein, minerals and vitamins and hence may be better diverted to contribute to alleviate the increasing global demand for protein (Lynch et al., 2018; Toldra et al., 2019).

Beef liver, heart and lung, in the content of protein and macronutrients, including Fe, K, E, C vitamins, etc., significantly exceed the meat. Replacing $75 \%$ of pork and beef on the liver, heart and lung in a ratio of 1: 1: 1 allows to keep the level of $\mathrm{Ca}$ and $\mathrm{Mg}$ content, increase $\mathrm{Fe}$ content by 2.2 times, and vitamins like, A, E, C (practically absent in meat), increase by 2.0; 0.52 and $9.75 \mathrm{mg}$ per $100 \mathrm{~g}$ of product, respectively.

The works of many authors are devoted to the development of formulations for combined meat products enriched with biologically active plant components (Chomanov et al., 2012; Volosenko \& Volosenko, 2017; Kajibayeva et al., 2013; Kehlet et al., 2019; Antonini et al., 2020; Rodrigues et al., 2020).

In the study of Ghafouri-Oskuei et al. (2020), the chemical properties and sensory attributes of beef sausages which have been incorporated with three tomato powder levels $(0,1.5$ and $3 \%)$ and three flaxseed powder levels ( 0,3 and $6 \%)$ were investigated. The addition of tomato and flaxseed powders decreased $(P<.001) \mathrm{L}^{\star}$ values, $\mathrm{pH}$, residual nitrite and moisture contents and increased $\mathrm{b}^{*}$ value $(P<.001)$, protein, carbohydrate, ash, fiber and total calories contents. The nitrite content decreased during the storage time. 


\section{Materials and methods}

$\mathrm{pH}$, moisture, ash, the content of protein, fat, sodium nitrite, carbohydrates, etc. have been determined in the finished meat products. $\mathrm{Ca}, \mathrm{Na}, \mathrm{K}, \mathrm{Mg}, \mathrm{Fe}$ - were determined by the method of atomic absorption on an atomic absorption spectrophotometer. Vitamins were determined by the method of high effective liquid chromatography (HELC). The analysis of free and combined with amino acids was carried out on an automatic analyzer of amino acids AAA 400.

\section{Results and discussion}

Proceeding from the fact that the inclusion of fruits and vegetables in the prescription is one of the ways of vitaminization of meat products, we included carrots into the sausage formula. In the development of recipes for these meat products, 6-8 experiments were carried out on model samples under laboratory conditions. After the development of model samples, tasting was conducted. The optimal doses of the utilization of heart $(10 \mathrm{~kg})$ and carrots $(7 \mathrm{~kg})$ per $100 \mathrm{~kg}$ of raw material were determined by experimental way on the model samples.

Researches on the development of the formulation of new types of meat products were carried out under the laboratory conditions. Raw materials grounded in a meat grinder. Experimental model samples were carried out in the amount of 200-250 g of meat. Roasting and cooking were carried out under the conditions corresponding to industrial production, then the samples were cooled under a shower of cold water for $8 \pm 2$ minutes. To a temperature of $+2{ }^{\circ} \mathrm{C}$ to $+15^{\circ} \mathrm{C}$ in the center of the product.

Research was carried out in the production of new experimental types of sausage, in comparison with sausages traditionally produced by the industry. In order to obtain a more complete volume of information, samples for analysis were taken at various technological stages (sediment, roasting, cooking, cooling, finished product).

It is evident that in the production of meat products they undergo this or that heat treatment, in which vitamins and other biologically active substances can be destroyed, suffer quantitative and qualitative changes in proteins, fats, carbohydrates, minerals, etc. At the same time, significant changes in the quality of finished products and their nutritional value are possible.

In this connection, the changes in the physicochemical and biological parameters of the prototype sample of sausages at different technological stages were studied. The results of studying the physicochemical parameters depending on the different technological stages of the experimental samples of sausages 1,2 and the traditionally produced sample are shown in Figures 1-4.

The analysis of the data shows that in the process of heat treatment the parameters: $\mathrm{pH}$, humidity level, fat, sodium nitrite are reduced.

As seen in Figure 1, the initial pH (5.9-6.0) in the test samples in the stages of precipitation and roasting, and after cooking and cooling (the finished product), the $\mathrm{pH}$ is reduced to 5.5. In the traditionally produced samples, the initial pH (5.8) decreases after roasting to 5.7, to a value of 5.6 in the finished product.

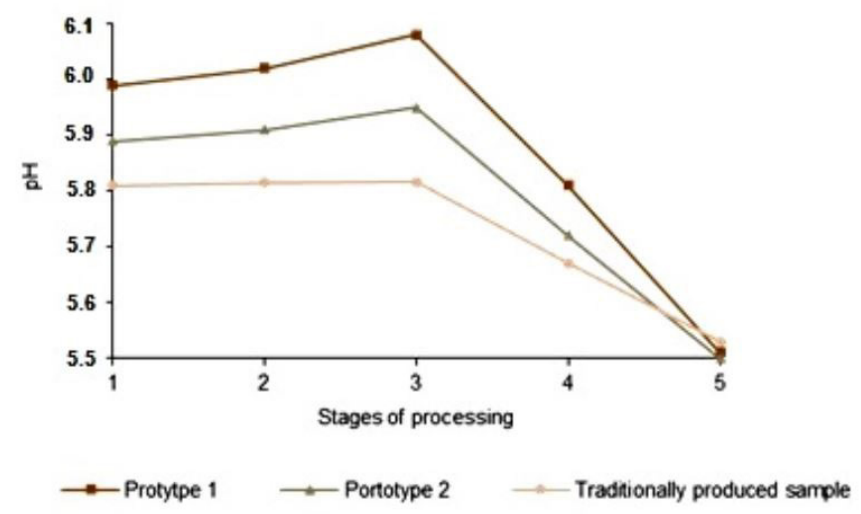

Figure 1. Changes in $\mathrm{pH}$ values at different stages of sausage production technology: (1) raw forcemeat; (2) after precipitation; (3) after roasting; (4) after cooking; (5) finished product.
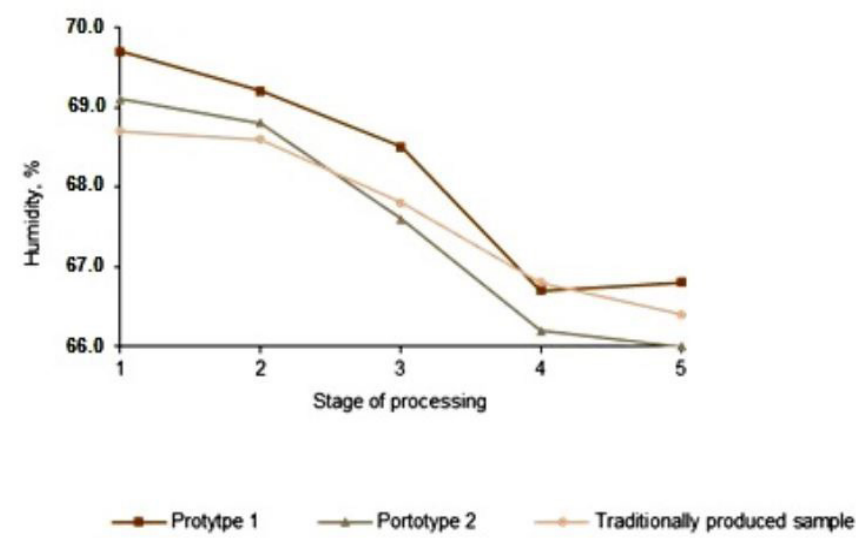

Figure 2. Change in humidity at different stages of sausage production technology: (1) raw forcemeat; (2) after precipitation; (3) after roasting; (4) after cooking; (5) finished product.

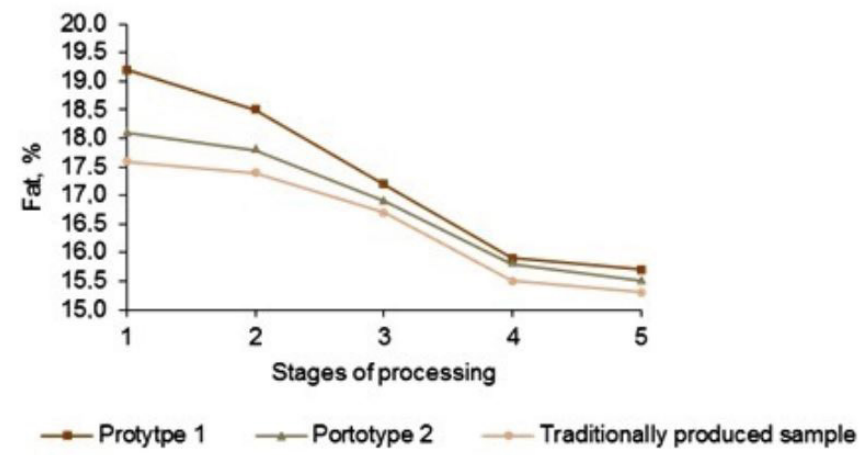

Figure 3. Change in fat content at various stages of sausage production technology: (1) raw forcemeat; (2) after precipitation; (3) after roasting; (4) after cooking; (5) finished product.

Humidity in samples of all types of sausages during the thermal treatment naturally decreases (to 66.0, 66.7 and 67.3\%, respectively) (Figure 2). Decrease in humidity due to natural loss of water during roasting, cooking, etc.

If the fat content in raw minced meat of prototypes and traditionally produced sausages is $19.3,17.9$ and $18.1 \%$, respectively, 


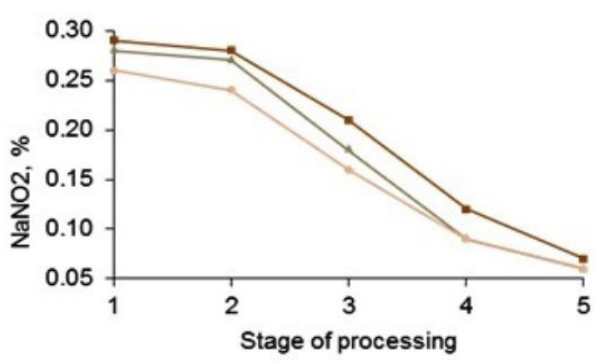

$\because$ Protytpe

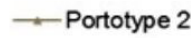

$\ldots$ Traditionally produced sample

Figure 4. Change in the content of sodium nitrite at different stages of sausage production technology: (1) raw forcemeat; (2) after precipitation; (3) after roasting; (4) after cooking; (5) finished product.

Table 1. Physicochemical parameters of prototypes of sausages.

\begin{tabular}{lcc}
\hline \multicolumn{1}{c}{ Indicators } & Prototype 1 & Prototype 2 \\
\hline Vitamins, ${ }^{2} \%:$ & & \\
$\mathrm{B}_{1}$ & 0.50 & 0.30 \\
$\mathrm{~B}_{2}$ & 5.80 & 0.25 \\
$\mathrm{PP}$ & 2.80 & 3.80 \\
Minerals,mg\%: & & \\
$\mathrm{K}$ & 310.00 & 303.00 \\
$\mathrm{Na}$ & 330.00 & 338.50 \\
$\mathrm{Ca}$ & 45.10 & 30.90 \\
$\mathrm{Mg}$ & 25.00 & 10.50 \\
$\mathrm{Fe}$ & 4.10 & 3.20 \\
$\mathrm{pH}$ & 5.50 & 5.50 \\
Humidity,\% & 66.00 & 67.50 \\
Fat,\% & 15.00 & 14.60 \\
Protein,\% & 14.50 & 14.60 \\
Sodium nitrite,\% & 0.035 & 0.033 \\
Carbohydrates,\% & 1.50 & 0.70 \\
Cinder,\% & 2.15 & 1.99 \\
\hline
\end{tabular}

Table 2. Organoleptic characteristics of production prototypes of sausages.

\begin{tabular}{lcc}
\hline \multicolumn{1}{c}{ Parameters } & $\begin{array}{c}\text { Production prototypes } \\
\text { Sample 1 }\end{array}$ & $\begin{array}{c}\text { Production prototypes } \\
\text { Sample 2 }\end{array}$ \\
\hline $\begin{array}{l}\text { Organoleptic } \\
\text { indicators } \\
\text { (on a 5- point scale) }\end{array}$ & & \\
Marketable state & $4.50 \pm 0.43$ & $4.00 \pm 0.32$ \\
Color on incision & $5.00 \pm 0.54$ & $4.00 \pm 0.32$ \\
Consistency & $4.50 \pm 0.42$ & $4.50 \pm 0.42$ \\
Juicy & $4.80 \pm 0.50$ & $4.50 \pm 0.40$ \\
Smell and flavor & $4.50 \pm 0.40$ & $4.50 \pm 0.42$ \\
Taste & $4.80 \pm 0.50$ & $4.50 \pm 0.40$ \\
General assessment & $4.80 \pm 0.50$ & $4.50 \pm 0.41$ \\
\hline
\end{tabular}

then gradually decreasing in the process of technology, especially after roasting and cooking, its finished product is 15.3, 15.5 and $15.5 \%$ (Figure 3). Decrease in its level is explained by its passage into the broth.
The level of sodium nitrite in samples of all types of sausages (Figure 4) gradually decreases by 4.3-4.5 times and reaches a level of 0.06-0.07 in the finished products, which is due to its decrease under the influence of temperature and interaction with a number chemical compounds.

Organoleptic parameters, $\mathrm{pH}$, moisture, ash, fat, protein, vitamins, minerals, carbohydrates, sodium nitrite were determined in finished meat products (Table 1).

As can be seen from the table, both variants of sausages are similar in quality composition, but for their quantitative composition they differ. The prototype sample 2 contains more vitamin $\mathrm{PP}$ (3.80 $\mathrm{mg} \%$ versus. $2.80 \mathrm{mg} \%$ ), and the test sample 1 contains more vitamin $\mathrm{B}_{2}$ (5.80 $\mathrm{mg} \%$ versus. $\left.0.25 \mathrm{mg} \%\right)$, as well as calcium $(45,10 \mathrm{mg} \%$ versus $30,90 \mathrm{mg} \%)$ of iron $(4,10 \mathrm{mg} \%$ versus. 3,20 mg\%), magnesium - more than 2 times. According to the content of vitamin $\mathrm{B}_{1}$, the options are not significantly different. The caloricity content of both types of products are almost the same.

Assessment in the first stage of the experiments was carried out for organoleptic parameters using the Q methodology (Table 2) (Vidal et al., 2020). It is established that, the greatest overall rating $(4.80 \pm 0.5)$ on marketable type, color incision, juicy, taste received sausages 1 . Sausages 2 had a slightly less bright color due to the presence of fiber. According to the aroma, the consistency of both samples are estimated at 4.5 points.

The aim of our investigation is also the determination of the state of qualitative and quantitative composition of free and bound amino acids in the meat base in the process of making meat products, taking into account the state of other biological components in them. In the test sample, the content of free amino acids was studied. The results of the investigation are presented in the Table 3.

The investigation of the content of free amino acids in the obtained samples of sausages showed that the prototype sample 1 contains all free amino acids, in contradiction to the experimental sample 2, where leucine and tryptophan are absent, and arginine is detected as traces. In the test sample 1 , there is more phenylalanine, tyrosine, glycine $(0.86,0.83,0.62 \mathrm{~g} / \mathrm{kg}$, respectively). The prototype test 2 has higher indices of aspartic acids, lysine, and also isoleucine, alanine, glutamic acid, serine, threonine. The total amount of free amino acids in the test sample 1 is $8.98 \mathrm{~g} / \mathrm{kg}$ versus 7.02 in the test sample 2 .

In the test samples of sausages, bound amino acids were also studied. Data on the determination of bound amino acids are presented in the Figure 5.

Both variants do not differ in the qualitative composition of the bound amino acids, as well as the both variants contain a complete set of amino acids, both nonessential and essential, but in terms of their quantitative content they differ, with the exception of lysine, practically the level of all amino acids is higher in the test sample of sausages 1 . The most significant differences in histidine (6.65 vs. $2.05 \mathrm{~g} / \mathrm{kg}$ ), asparagine (7.55 vs. $4.00 \mathrm{~g} / \mathrm{kg})$, glycine (8.95 vs. $4.75 \mathrm{~g} / \mathrm{kg})$, glutamic acid (9.30 vs. $4.20 \mathrm{~g} / \mathrm{kg})$, alanine (6.85 vs. $3.00 \mathrm{~g} / \mathrm{kg})$, valine ( 8.40 vs. $4.00 \mathrm{~g} / \mathrm{kg})$ and leucine (15.20 versus $7.95 \mathrm{~g} / \mathrm{kg}$ ). 
Table 3. The content of free amino acids in the experimental samples of sausages.

\begin{tabular}{lcc}
\hline \multirow{2}{*}{ Amino acids } & \multicolumn{2}{c}{ Content, g/kg } \\
\cline { 2 - 3 } & Prototype 1 & Prototype 2 \\
\hline Aspartic acid & 0.37 & 0.73 \\
Threonine & 0.14 & 0.20 \\
Serin & 0.34 & 0.49 \\
Glutamic acid & 1.09 & 1.41 \\
Glycine & 0.62 & 0.52 \\
Alanin & 0.75 & 1.00 \\
Valine & 0.37 & 0.38 \\
Methionine & 0.18 & 0.19 \\
Isoleucine & 0.32 & 0.46 \\
Leucine & 2.73 & - \\
Tyrosine & 0.83 & 0.63 \\
Phenylalanine & 0.86 & 0.63 \\
Lysine & 0.11 & 0.19 \\
Histidine & 0.11 & 0.12 \\
Tryptophan & Vestiges & - \\
Arginine & 0.09 & Vestiges \\
Cysteic acid & 0.07 & 0.07 \\
Total amino acids & $\mathbf{8 . 9 8}$ & 7.02 \\
\hline
\end{tabular}

\section{Prototype 1}

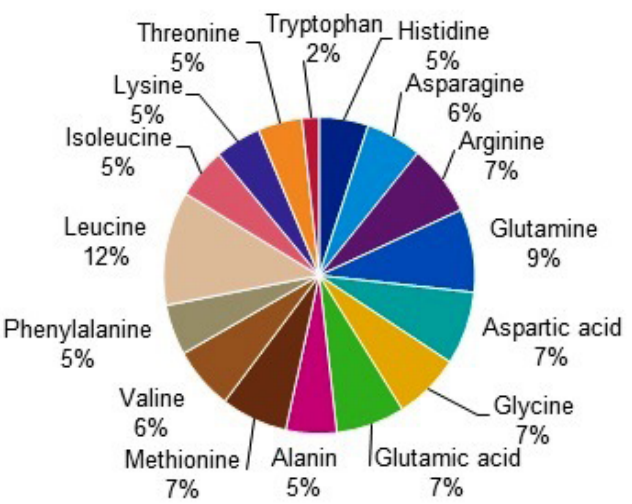

Prototype 2

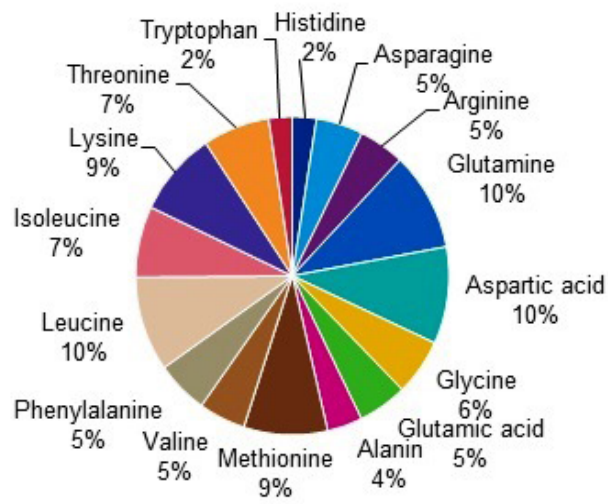

Figure 5. The content of bound amino acids in the experimental samples of sausages.

The content of such essential amino acids as valine, histidine, arginine, isoleucine, leucine, methionine, threonine, tryptophan, phenylalanine, lysine in samples 1 and 2 was 58.9 and $60.8 \%$ of the
Prototype 1

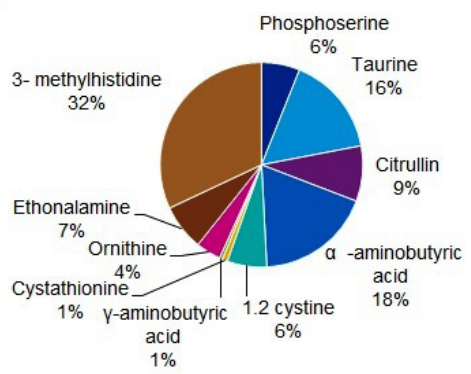

Prototype 2

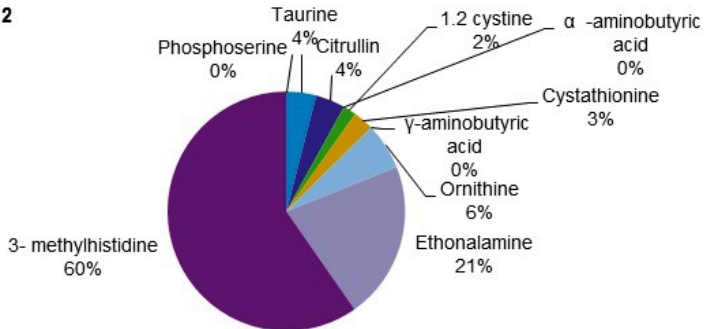

Figure 6. The content of derivatives of free amino acids in the experimental samples of sausages.

total bound amino acid content. But the total number of amino acids is higher in the test sample 1 .

In the test samples of sausages, the content of free amino acid derivatives were also determined (Figure 6).

The qualitative composition of the amino acid derivatives in the experimental sausage samples differs: in the samples 2 there is absence of phosphoserine, $\gamma$-aminobutyric acid, and $\gamma$-aminobutyric acid is contained in traces. The content of these compounds in the sample 1 is respectively $0.37 ; 0.03$ and $0.11 \mathrm{~g} / \mathrm{kg}$. In the samples 2 there contain more than 3 -methylhistidine $(2.36 \mathrm{~g} / \mathrm{kg})$. The sample 1 has a higher level of taurine, citrulline and 1.2 cystine $(0.96,0.53$, and $0.38 \mathrm{~g} / \mathrm{kg}$, respectively). The total sum of amino acid derivatives is also higher in the test sample 1 (5.04 versus 3.95 , respectively).

\section{Conclusion}

1. As a result of the investigation, the prescription of two new combined meat products have been carried out;

2. The inclusion of offal ( $10 \%$ of heart muscle) and vegetable filler ( $7 \%$ of carrot) in the sausage co-products formulation is conditioned in economizing of high-grade meat and enriches finished products with vitamins, micro- and macro elements;

3. It is shown that at the stage of heat treatment the content of moisture and fat decreases, the amount of sodium nitrite decreases to trace amounts;

4. The qualitative composition of vitamins and mineral substances of sausages, both in the first and in the second variant, turned out to be similar, but differing in their quantitative content. In the sample $\mathbf{1}$ there is more vitamin $\mathrm{B}_{2}$, magnesium and iron; 
5. The qualitative and quantitative composition of free and bound amino acids of meat products proteins was determined. Their usefulness have been shown in relation to the nonessential and limiting amino acids, on the content of proteins, fats, carbohydrates, etc.;

6. Sausages differ in the qualitative and quantitative composition of free amino acids. Sample 1 contains all free amino acids, unlike the carrot sample, where there is lack of leucine, tryptophan, but arginine is detected as traces. The total amount of amino acids in sausages 1 contains $8.88 \mathrm{~g} / \mathrm{kg}$ vs. $7.02 \mathrm{~g} / \mathrm{kg}$ in sample 2;

7. The qualitative composition of the bound amino acids in sausages is the same, but the quantitative content is different. The amount of bound amino acids in sausages 1 is 130.30 , but in the sample 2 , is $82.70 \mathrm{~g} / \mathrm{kg}$.

\section{References}

Antonini, E., Torri, L., Piochi, M., Cabrino, G., Meli, M. A., \& De Bellis, R. (2020). Nutritional, antioxidant and sensory properties of functional beef burgers formulated with chia seeds and goje puree, before and after in vitro digestion. Journal Meat Science., 161, 108021. http://dx.doi.org/10.1016/j.meatsci.2019.108021. PMid:31809915.

Aslanova, M. A., Derevitskaya, O. K., Daljin, A. S., \& Volovik, E. L. (2010). Functional products on meat basis, enriched with plant raw materials. Journal Meat Industry, 6, 45-47.

Chomanov, U. Ch., Tultabaeva, T.Ch, Urazbayeva, K.A., Kenenbay, G.S., \& Zhilkaidarov, A.N. (2012). Development of the recipe for combined meat products based on co-products and vegetable raw materials. Bulletin of the National Academy of Sciences of the Republic of Kazakhstan, 2, 55-58.

Ghafouri-Oskuei, H., Javadi, A., Saeidi Asl, M. R., Azadmard-Damirchi, S., \& Armin, M. (2020). Quality properties of sausage incorporated with flaxseed and tomato powders. Journal Meat Science, 161, 107957. http://dx.doi.org/10.1016/j.meatsci.2019.107957. PMid:31785513.

Kajibayeva, Q. T., Asenova, B. K., \& Smolnikova, F. X. (2013). Development of functional meat products enriched with food fibers and minerals. In Wptyw Badan Naukowych (Zbior Raportow Naukowych, pp. 52-55). Bydgoszcz: Sp. z o.o. «Diamond trading tour».

Karwowska, M., Wojciak, K. M., \& Dolatowski, Z. J. (2014). Comparative studies on lipid oxidation of organic model sausage without nitrite produced with the addition of native or autoclaved mustard seed and acid whey. International Journal of Food Science \& Technology, 49(12), 2563-2570. http://dx.doi.org/10.1111/ijfs.12586.
Kehlet, U., Christensen, L. B., Raben, A., \& Aaslyng, M. D. (2019). Physico-chemical, orosensory and microstructural properties of meat products cantaining rye bran, pea fibre or a combination of the two. International Journal of Food Science \& Technology, 55(3), 1010-1017. http://dx.doi.org/10.1111/ijfs.14326.

Kryževičūte, N., Jaime, I., Diez, A. M., Rovira, J., \& Venskutonis, P. R. (2017). Effect of raspberry pomace extracts isolated by high pressure extraction on the quality and shelf-life of beef burgers. International Journal of Food Science \& Technology, 52(8), 1852-1861. http:// dx.doi.org/10.1111/ijfs.13460.

Lynch, S. A., Mullen, A. M., O’Neill, E., Drummond, L., \& Álvarez, C. (2018). Opportunities and perspectives for utilisation of coproducts in the meat industry. Meat Science, 144, 62-73. http:// dx.doi.org/10.1016/j.meatsci.2018.06.019. PMid:29945746.

Pluschke, A. M., Feng, G., Williams, B. A., \& Gidley, M. J. (2018). Partial replacement of meat by sugar cane fibre: cooking characteristics, sensory properties of beef burgers and in vitro fermentation of sugar cane fibre. International Journal of Food Science \& Technology, 54(5), 1760-1768. http://dx.doi.org/10.1111/ijfs.14069.

Rodionova, N. S., Popov, E. S., Radchenko, A. Y., \& Kolesnikova, T. N. (2015). Development of balanced vegetable food systems on the basis of products of domestic plant raw materials processing. In Proceedings of the II International Scientific and Technical Conference "Innovative technologies in the Food Industry: Science, Education and Production" (pp. 59-61). Voronezh.

Rodrigues, A. S., Kubota, E. H., Silva, C. G., Alves, J. S., Hautrive, T. P., Rodrigues, G. S., \& Campagnol, P. C. B. (2020). Banana inflorescences: a cheap raw material with great potential to be used as a natural antioxidant in meat products. Journal Meat Science., 161, 107991. http://dx.doi.org/10.1016/j.meatsci.2019.107991. PMid:31710885.

Toldra, M., Pares, D., Saguer, E., \& Carretero, C. (2019). Utilisation of protein fractions from porcine spleen as technofunctional ingredients in emulsified cooked meat sausages. International Journal of Food Science \& Technology, 55(2), 871-877. http://dx.doi.org/10.1111/ijfs.14298.

Tyugai, M. I. (2004). Development of the technology of cooked sausages using the properties of filler based on onions and carrots: the thesis. Moscow, Russia.

Vidal, V. A. S., Paglarini, C. S., Freitas, M. Q., Coimbra, L. O., Esmerino, E. A., Pollonio, M. A. R., \& Cruz, A. G. (2020). Q methodology: an interesting strategy for concept profile and sensory description of low sodium salted meat. Journal Meat Science, 161, 108000. http:// dx.doi.org/10.1016/j.meatsci.2019.108000. PMid:31707157.

Volosenko, L. V., \& Volosenko, S. S. (2017). Functional meat products using non-traditional plant materials. In Proceedings of the IV International Scientific and Technical Conference "Innovative Technologies in the Food Industry: Science, Education and Production" (pp. 20-23). Voronezh. 